\title{
BROODINESS INSTINCT IN FARM POULTRY: REALIZATION AND METHODS OF SUPPRESSION
}

\section{O.I. STANISHEVSKAYA, E.S. FEDOROVA, N.V. PLESHANOV}

\author{
All-Russian Research Institute for Farm Animal Genetics and Breeding, Federal Agency of Scientific Organizations, \\ 55A, Moskovskoe sh., pos. Tyarlevo, St. Petersburg-Pushkin, 196625 Russia, e-mail olgastan@list.ru (correspond- \\ ing author), fedorova816@mail.ru, klaus-90@list.ru \\ ORCID: Stanishevskaya O.I. orcid.org/0000-0001-9504-3916 \\ The authors declare no conflict of interests \\ Acknowledgements: \\ Supported by Russian Science Foundation (project № 16-16-04060) and the Federal Agency for Scientific Organi- \\ zations program for the bioresource collections
}

Received April 26, 2017

\section{Abstract}

Many hens of gene pool populations along with their breed features are characterized by the manifestation of such a trait as broodiness which has been lost in commercial lines and breeds. This trait has some negative impact at commercial farming, because during the nesting period the hens stop egg laying that leads to decreasing in egg performance and the number of progeny. Predisposition to the broodiness is an inherited trait and its eradication can be achieved by use of selection methods. But elimination of the families with high levels of nesting will lead to the destroying of the genetic structure in the gene pool population. Hormonal methods and technological shocks (electric current, high-intensity light and transfer to the new environmental conditions) may also be used to suppress broodiness instinct. But some of them could be not available technically and other ones should not be applicable ethically. In our research, the Chinese silky chickens (Gallus gallus) from the gene pool collection of All-Russian Research Institute of Farm Animal Genetics and Breeding which are characterized by highly developed broodiness served as a model. In individual cage batteries the occurrence of broodiness instinct resulted in specific behavioral reactions and refusing in the majority of cocks to give sperm to massage. In the group keeping of birds on the floor, the presence of cocks to some extent stimulated the hens to lay eggs. But during the entire productive period about 70-75\% of hens demonstrated nesting behavior and did not lay eggs. Most part of cocks also showed specific behavior and did not mate with hens. This led not only to the low yield of hatching eggs from a pen, but also to the loss of a large number of genotypes of both hens and cocks in the reproduction of the flock. In order to suppress the broodiness instinct in Chinese silky hens, contained in individual cages, we used injection of native mixed sperm of cocks into the oviduct or cloaca of the hens. The insemination of the hens (three inseminations with 4-day intervals) started four weeks prior to the breeding season. During two experiments about $70 \%$ of all hens responded to the stimulation by restarting of oviposition or increasing of egg performance. The frequency of occurrence of individuals with a high laying intensity (51-60\% and higher) increased, while frequency of hens with low egg laying rate went down. This method of broodiness suppression is more preferable and more physiologically acceptable in comparison to the traditional shock methods, but with the same efficiency.

Keywords: broodiness, artificial insemination, gene pool preservation, egg performance

One of the important tasks of modern poultry farming is the preservation of gene pool breeds. Programs for the conservation of genetic resources of local, rare and endangered species operate in many countries. Gene pool breeds not only serve as a reservoir of potentially valuable alleles and genes for breeding, but also have a number of advantages over commercial poultry: high viability in an extensive breeding system without strict vaccination regulations; high taste and nutritional properties of meat and eggs; an anything goes attitude to the diet and the ability to assimilate local poultry feed production; attractive coloring of plumage, etc. $[1,2]$.

Many gene pool breeds, along with other features, possess such a property 
as an instinct of broodiness lost by the commercial poultry. In modern conditions, due to the widespread distribution of artificial incubation, this sign has lost its practical importance for the reproduction and extension of the species, being more likely a factor that damages commercial poultry farming. This is especially true for poultry with low egg productivity, as during broodiness, hens stop egg laying, which significantly reduces the yield of commercial and hatching eggs and, accordingly, the chickens for replacement stock. However, there is evidence that within the breed, a poultry inclined to broodiness has a higher vitality and survival compared to species that have lost such an instinct.

Predisposition to broodiness is a hereditary trait. Thus, modern breeds of chickens of Mediterranean origin (egg type) almost do not show the instinct of broodiness. However, among chickens of Asian origin (meat type), brooding hens are often found. The fact that in equal conditions in some breeds (Rhode Island, Russian White) this instinct is almost completely lost and almost does not manifest itself but in others (Chinese silky, Bentam) is preserved to some extent, also points to its hereditary nature. In early genetic studies, it was suggested that there are factors in the sex $\mathrm{Z}$ chromosome of the hen that determine the behavior of the female broodiness [3, 4]. So, back in 1930, D.C. Warren [3], carrying out reciprocal crosses of the White Leghorn breed, with a weak instinct of broodiness (in $5 \%$ of hens), with the Rhode Island Red breed, in which this instinct is observed in $83 \%$ of hens, reported sex-linked heritability of the studied trait. At the same time similar results were obtained by E. Roberts and L. Card [4]. However, when testing the hypothesis by hybridologic analysis in special crosses between White Leghorn chickens without the instinct of broodiness and Bentam chickens that hatch eggs, it was showed that the broodiness behavior is apparently not controlled by one main gene (or several genes) in the $\mathrm{Z}$ chromosome. If such a gene exists, it participates in activation of the broodiness process in addition to two interacting autosomal genes, one of which represses the other [5-7].

As is known, hypothalamus, pituitary gland and genital glands are involved in regulation of poultry sexual function. Under appropriate conditions, a prolactin-releasing factor is formed in the hypothalamus of females. Under its influence in the anterior lobe of the pituitary gland the main hormone of broodiness, prolactin, is produced. In the broodiness period, in the pituitary gland of females the basophilic cells disappear, and oxyphilic cells appear in large quantities (lactotropocytes) which are even figuratively called "broodiness cells". The injection of prolactin or the blood of hatching chickens to males and egg-laying hens leads to the development of a characteristic broodiness behavior [8]. Prolactin suppresses the secretion of gonadotropins in female poultry, i.e. folliclestimulating and luteinizing hormones, and also has a depressing effect on the secretion of sex hormones, reduces the steroid activity of the ovary. Therefore, during the broodiness and young-stock breeding, sexual behavior is absent, and the hens do not mate [9-12].

A 24 bp insertion (nucleotides in positions 377-354) was found in the promoter region of the prolactin gene (-358 PRL, Chr2, GenBank AB011438). The presence of the insertion has been studied in detail by various research groups, and it has been found that it positively correlates with the rate of oviposition in poultry and negatively correlates with the instinct of broodiness. The individuals with heterozygous genotype In/Del have the highest prolactin mRNA level [13-16]. Genetic changes in the prolactin-receptor prolactin regulation system, which lead to inhibition of their activity, can be used as genetic markers for rearing hens with a decreased instinct of broodiness and, as a consequence, with increased egg productivity [17-19]. 
Thus, using selective genetic methods, it is possible to rid the population of individuals with a pronounced instinct of broodiness. In commercial poultry farming, in particular, in the turkey farming, in which this instinct still manifests to a larger extent, such methods are widely used along with hormonal [20-22] and technological approaches, involving various types of shock effects on the poultry (electric current, high intensity light, transfer to the new environmental conditions), that is not always possible for technical and ethical reasons [23, 24]. In small gene pool breeds, the elimination of families that show the instinct of broodiness will inevitably lead to a narrowing genetic diversity, a disturbance of the breed genetic structure and will increase breed extinction risk. Therefore, other methods are needed for formation control of the instinct of broodiness that do not adversely affect the breed genetic structure and are easy to apply.

In this paper, we are the first to propose the use of natural biological mechanisms that allow the activation of ovulation and egg formation in laying hens due to a special factor contained in the male sperm, in order to suppress the instinct of hatching. We have not found reports about such experiments on poultry in the world's scholarly publications.

The purpose of the research was to develop a technique that would suppress the instinct of broodiness in hens of the gene pool breeds to stimulate the process of ovulation and successful reproduction.

Techniques. Chinese silky chickens (Gallus gallus) were chosen as a model. Farm experiments were carried out in 2015-2016 (experiment I) and in 20162017 (experiment II) (Genetic Collection of Rare and Endangered Chicken Breeds, the Genofond Branch VNIIGRZh, Leningrad Province). The age of the poultry was 24-45 and 28-53 weeks (the difference in the chicken age by years is due to differences in technological schedules in the farm). The poultry of the experimental groups ( $n=17$ in experiment I and $n=25$ in experiment II) were kept in individual cages up to weeks 56-60 of life with artificial insemination and individual daily egg-laying record. Broodiness instinct was controlled and stimulation was performed. In the control groups $(n=25$ in experiment $\mathrm{I}, n=17$ in experiment II) chickens up to the same age were kept in flooring sections together with the cocks for natural mating. The group productivity was recorded daily, sand the hatching hens were under control. Feeding and housing technologies were as generally accepted for gene pool breeds. There were no differences in the origin of the poultry between the groups. The laying hens were fed with a complete fodder PK-1-1 (16.4\% of crude protein, $258 \mathrm{kcal} / 100 \mathrm{~g}$ of metabolic energy). After the end of the poultry use, the data was summarized to determine the final productivity of the hens.

Intensity of egg laying $(\mathrm{I}, \%)$ was calculating as $\mathrm{I}=(\mathrm{B} \times 100) /(\mathrm{D} \times \mathrm{P})$, with $\mathrm{B}$ as the total number of laid eggs over a period, D as the number of days in the period, and $\mathrm{P}$ as the number of laying hens in the group.

To suppress the instinct of broodiness and to stimulate ovulation, native mixed sperm of cocks, obtained by massage, was injected into the oviduct or cloaca (in the case of insemination when the oviduct cannot be removed) at a dose of $0.05 \mathrm{~cm}^{3}[26,27]$. The insemination of chickens began 4 weeks before the breeding season ( 3 inseminations with a 4-day interval). The influence of stimulation was traced in dynamics, for which the count of the number of laid eggs and the intensity of egg laying were estimated in three conventional time intervals, i.e. i) from the beginning of the accounting period of oviposition to insemination (44-67 days, depending on the technological schedule); ii) during the insemination period ( 4 weeks before the breeding season and during the breeding season), and also within 3 weeks after it, as the sperm of the cocks can remain in the genital tracts of the hens within 3 weeks without losing fertility [26] (62- 
74 days); iii) 3 weeks after the final insemination and until the end of the accounting period (35-46 days).

In the statistical processing of the intensity of oviposition per group, with regard to the period of the experimental treatment, the mean $(M)$ and standard error of the mean $( \pm S E M)$ were calculated. The significance of differences was evaluated by Student's $t$-test. The differences were considered statistically significant at $\mathrm{P}<0.05$.

Results. The theoretical background for the study was the known data that in animals, for which induced ovulation is characteristic, the corresponding mechanism is triggered by a special factor contained in the sperm of males, the protein $\beta$-NGF ( $\beta$-growth factor of nerve tissue) which can be found in almost all mammals, including humans. It has been established that $\beta$-NGF provokes ovulation in many mammalian species that are characterized by induced ovulation. In animals with regular ovulation, $\beta$-NGF does not induce it, but has a positive effect on the fertility of the female and behaves like a female sex hormone [25].

In the available publications, information on similar studies carried out on poultry was not found, but it was suggested that such a mechanism belongs to general biological ones, including birds.

The Chinese silky breed used as a model refers to the decorative one. The weight is $1.0-1.4 \mathrm{~kg}$ for the hens, and $1.2-1.7 \mathrm{~kg}$ for the cocks. Hens can lay up to 80 light brown eggs per year weighing $40-41 \mathrm{~g}$ each. The choice of this breed for research is due to their strong instinct of broodiness. The hens of this breed are often used for hatching quail and pheasant eggs and taking care of the young poultry. We do not consider it permissible to eradicate the instinct of broodiness, as a breed specific feature, in this breed. However, it is necessary to suppress this instinct for a certain period of time to successfully reproduce the population and preserve genetic diversity in the breed.

In our experiments, due to the battery cage for housing used, the poultry did not contact the litter and the laid eggs, which to some extent hindered the instinct of broodiness, but did not completely suppress it, and the behavior characteristic of the early stages of natural hatching is still developed (clucking, appearing of brood-patches on the chest and abdomen). In the Chinese silky breed poultry, even under cage housing, there was a mass manifestation of the broodiness instinct, which additionally led to characteristic behavioral response in a large number of cocks who at that time refused to give sperm to massage.

It was found that the intensity of oviposition varied within $30-39 \%$ in the control group when flooring housing used. Apparently, the presence of cocks to some extent stimulated chickens to oviposition, however, during the entire productive period, about $70-75 \%$ of the population actively hatched and did not lay eggs. Most cocks also showed characteristic behavior, being in nests with hens and not mating. This led not only to a low yield of hatching eggs from the poultry housed in the sections, but also to the loss of a large number of genotypes of both hens and cocks during flock reproduction, which is critical for the preservation of gene pool in breeds with low egg-laying. For good reproduction of such populations, commercial breeders are forced to store additional egg set formed during breeding season, which is economically, veterinaryly and zootechnically inexpedient. Moreover, there is no guarantee that additional egg sets will reproduce all genotypes and preserve the genetic structure of the breed.

Obviously, the presence of cocks in the flock did not sufficiently stimulate the hens to oviposition and did not diminish the manifestations of broodiness. For that matter, we have used the method developed by us to stimulate ovulation by introducing the mixed native sperm of cocks into the chicken oviduct. 
Stimulation started 4 weeks before the beginning of the breeding season established in the farm, so that hens could adapt to the restoration of egg laying; at the beginning of the breeding season in the genital tracts of the female there were no viable spermatozoa, and hens were ready for a monosperm insemination by certain cocks.

Egg laying in Chinese silky breed chicken (Gallus gallus) hens depending on the response to stimulation of ovulation by native cock sperm during different periods

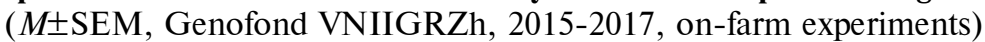

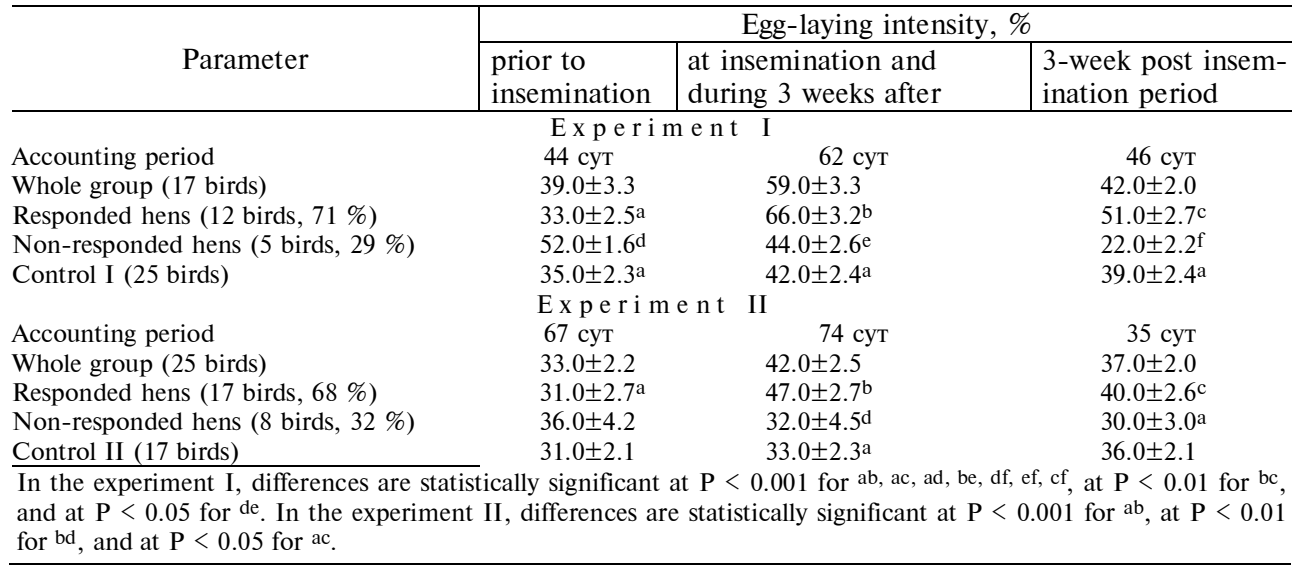

Stimulation of restored oviposition or increase in its intensity, as influenced by insemination, resulted in a positive effect in more than $2 / 3$ of the population. So, 71 and $68 \%$ of hens responded to stimulation in the experiment I and experiment II, respectively (Table). Basically, there were those hens whose instinct of broodiness is clearly pronounced and the periods of alternation of oviposition and broodiness are clearly traced. The other chickens did not respond to artificial insemination with native mixed sperm of cocks. Since the beginning of the first egg laying and until the end of commercial use, these hens showed almost no tendency to hatch and had a smooth curve of egg laying.

In the experiment $\mathrm{I}$, the oviposition has doubled in responding hens after insemination, from 33 to $66 \%$; during the third period, a regular decline in egglaying began. But, as we believe, due to the prolonged effect of stimulation, the decline was quite smooth, from 66 to $51 \%$. At the same time, the egg laying reduced from 52 to $22 \%$ (see Table) for the same 15 weeks in hens which did not respond to stimulation and showed the peak of egg laying intensity at the beginning of the survey. The results of the experiment II confirmed the regularity observed in the experiment I, i.e. a significant increase in the intensity of oviposition with a smooth decrease in the hens, responded to stimulation, and a steady decrease in egg laying in non-responded hens (see Table). The mixed sperm was used in the stimulation experiments to exclude the individual immunological incompatibility of hens and cocks and to level differences in the quality of sperm form different cocks.

As a result of both experiments, it was also found that insemination of hens led to an increase in the frequency of individuals with high oviposition. In the experiment I, before stimulation, the hens with egg production of $0-10 \%$ averaged $12 \%$ of the total population, reaching $29 \%$ for $11-30 \%$ egg laying and $30 \%$ for $61-80 \%$ egg laying. After insemination, the number of hatching hens with egg laying intensity of 61-80\% increased up to $47 \%(+17 \%)$, whereas the frequency of those with 11-30\% egg laying decreased by half, to $6 \%$, and no hens with egg laying of 0-10\% were observed (Fig., A). After 3 weeks from 
the last insemination, the frequency of hens with a rather high productivity for the breed decreased again. The number of hens with $0-10 \%$ egg laying increased to $18 \%$, the individuals with 11-30\% egg laying reached the initial level of 12 $\%$ observed in the population, and the ammount of hens with 61-80\% egg laying declined by half, to $24 \%$. At the same time, the portion of hens with an average productivity index of 31-60\% remained unchanged. In the experiment II, the frequency of hens with $0-10 \%$ egg laying remained within $4 \%$ of the population both before and after insemination. For 11-30\% egg laying, the hen number decreased from 40 to $16 \%$ after insemination and remained the same 3 weeks after. The number of hens with 31-50 \% egg production increased insignificantly $(+4 \%)$ after stimulation and remained equal to $48 \%$ of the population during the next 15 weeks. The frequency of highly productive hens with 51-60\% oviposition in the population increased after stimulation almost threefold, from 12 to $32 \%$, and then, 3 weeks after the last insemination, decreased to $24 \%$ which, however, is twice as high as the similar indicator before insemination (see Fig., B).

A

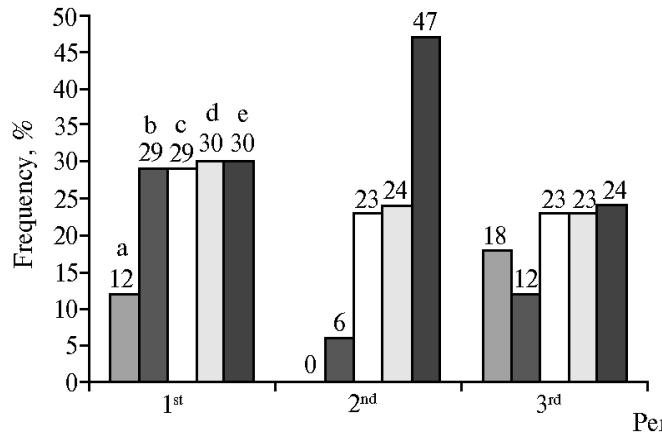

B

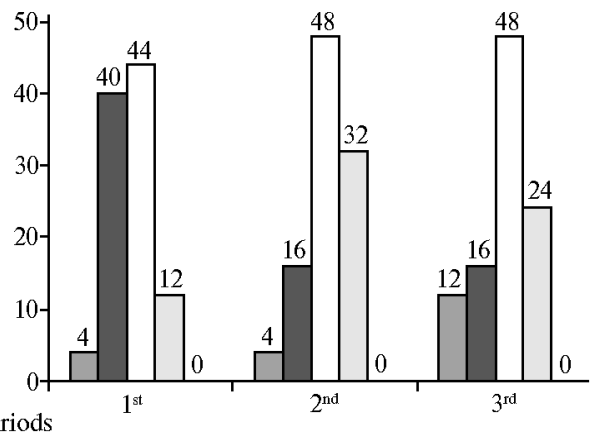

Occurrence of hens with different egg laying ability in the Chinese silky breed chicken (Gallus gallus) population under the influence of insemination by mixed sperm of cocks: A - experiment I $(n=17)$, B - experiment II $(n=25)$; 1st, 2nd and 3rd periods are before insemination, during insemination and during 3 weeks after insemination, and 3 weeks after insemination; intensity of egg laying of $10 \%$ (a), 11-3 0\% (b), 31-50\% (c), 51-60\% (d), and 61-80\% (e) (Genofond VNIIGRZh, 20152017, on-farm experiments).

Probably, the effect of hens' insemination is prolonged, which allows us not only to increase egg production in the whole flock, but also to increase the frequency of hens with higher values of this index. Thus, the proposed procedure of suppressing the instinct of broodiness in chickens by artificial introduction of the sperm of cocks in the genital tracts of the female is simple enough in execution, physiological in its nature and no less effective than the used hormonal methods and technological shocks.

Thus, it has been found out that in poultry, as in mammals, the introduction of native mixed sperm into the genital tracts of the female through artificial insemination serves as a factor that stimulates ovulation. The $\beta$-NGF protein present in the sperm of mammals is presumably also present in the sperm of poultry, particularly in cocks. Approximately $70 \%$ of hens respond to the stimulation of ovulation by the resumption of oviposition or an increase in egg laying, The frequency of individuals with a high percentage of egg laying (51-60\% or more) increases with a simultaneous decrease in the proportion of hens with a low egg laying. So stimulation of ovulation by 3-fold artificial insemination of hens, using native mixed sperm of cocks at a dose of $0.05 \mathrm{~cm}^{3}$ and 4 day intervals for 4 weeks prior to gathering of eggs for incubation, may be recommended to suppress the instinct of broodiness in hens before the breeding season. 


\section{R E F E R E N C E S}

1. G a l'p e r n I.L., S e g a 1 E.L., F e d o ro v I.V. Materialy XVIII Mezhdunarodnoi konferentsii «Innovatsionnoe obespechenie yaichnogo i myasnogo ptitsevodstva Rossii» [Proc. XVIII Int. Conf. «Innovative aspects of egg and meat poultry in Russia]. Sergiev Posad, 2015: 45-48 (in Russ.).

2. Stanishevskaya O.I., Cherepanov S.V., Vakhrameev A.B. Ptitseprom, 2016, 4(33): 64-68 (in Russ.).

3. W a r re n D.C. Crossbred roultry. Bulletin of Agricultural Experiment Station. Kansas, 1930.

4. Roberts E., Card L. The inheritance of broodiness in sross-bred poultry. International Review of Poultry Science, 1933, VII(1/2): 12-13.

5. Rom a nov M.N., T a lb ot R.T., Wils o n P.W., S h a r p P.J. Inheritance of broodiness in the domestic fowl. British Poultry Science Journal, 1999, 40(1): 20-21 (doi: 10.1080/00071669986611).

6. Ro m a n v M.N. Genetics of broodiness in poultry - a review. Asian-Australas. J. Anim. Sci., 2001, 14(11): 1647-1654 (doi: 10.5713/ajas.2001.1647).

7. Rom a nov M.N., T a lbot R.T., Wils o n P.W., S h a r p P.J. Genetic control of incubation behavior in the domestic hen. Poultry Science Journal, 2002, 81(7): 928-931 (doi: 10.1093/ps/81.7.928).

8. Meshchiryakova E.E. Tekhnologicheskie priemy profilaktiki proyavleniya $i$ podavleniya instinkta nasizhivaniya $u$ indeek $v$ tselyakh povysheniya ikh vosproizvoditel'nykh kachestv. Kandidatskaya dissertatsiya [Improvement of reproduction in turkey by means of brooding prevention and repression. PhD Thesis]. Moscow, 1985 (in Russ.).

9. R e d d y I.J., D avid C.G., S a r m a P.V., S i ng h K. The possible role of prolactin in laying performance and steroid hormone secretion in domestic hen (Gallus domesticus). General and Comparative Endocrinology, 2002, 127: 249-255.

10. Reddy I.J., David C.G., Khub Singh. Relationship between intersequence pauses, laying persistency and concentration of prolactin during the productive period in White Leghorn hens. Asian-Australas. J. Anim. Sci., 2005, 18(5): 686-691 (doi: 10.5713/ajas.2005.686).

11. Søre ns e n P. Chicken genetic resources used in Smallholder production systems and opportunities for their development. FAO, Rome, 2010.

12. Fathi M., Elyasi Zarringhobai e G. Association of polymorphisms in the promoter region of turkey prolactin with egg performance. Genetika, 2014, 46(2): 591-599 (doi: 10.2298/GENSR1402591F).

13. Wa ng J., Hou S.S., Huang W., Yang X.G., Z hu X.Y., Li u X.L. Molecular cloning of prolactin receptor of the Peking duck. Poultry Sci., 2009, 88: 1016-1022 (doi: 10.3382/ps.2008-00192).

14. Wang C., Liang Z., Yu W., Feng Y., Peng X., Gong Y., Li S. Polymorphism of the prolactin gene and its association with egg production traits in native Chinese ducks. South African Journal of Animal Science, 2011, 41: 64-69.

15. J i a ng R., C h e n X., W e i R., G e ng Z. Expression of plasma prolactin and pituitary prolactin mRNA around the broody cycle in Wan-xi White goose. Turk. J. Vet. Anim. Sci., 2011, 35(6): 431-434 (doi: 10.3906/vet-1003-328).

16. Kulibaba R.A., Podstreshnyi A.P. Prolactin and growth hormone gene polymorphisms in chicken lines of Ukrainian selection. Cytology and Genetics, 2012, 46: 390-395 (doi: 10.3103/S0095452712060060).

17. Cui J.X., Du H.L., Liang Y., Deng X.M., Li N., Zhang X.Q. Association of polymorphisms in the promoter region of chicken prolactin with egg production. Poultry Sci., 2006, 85: 26-31.

18. B agheri Sarvestani A.S., Niazi A., Zamiri M.J., Dadpas a d Taromsari M. Polymorphisms of prolactin gene in a native chicken population and its association with egg production. Iranian Journal of Veterinary Research, 2013, 14(2): 113-119.

19. Guo X., Fang Q., M a C., Z Z o u B., Wa n Y., Jiang R. Whole-genome resequencing of Xishuangbanna fighting chicken to identify signatures of selection. Genetics Selection Evolution, 2016, 48(1): 62 (doi: 10.1186/s12711-016-0239-4).

20. Kag y a -Ag y e mang J.K., She ndan S., Y in z u o B. Studies on the endocrine and neuroendocrine control of broodiness in the Yuehuang hen. International Journal of Poultry Science, 2012, 11(8): 488-495.

21. S qu i r e s E.J. Applied animal endocrinology. CABI Publishing, 2003.

22. Reddy I.J., Ravi Kiran G., Mondal S.K., Anandan S. Prolactin, luteinizing hormone and steroid hormone concentration in Punjab Brown (PB3) birds immunized against vasoactive intestinal peptide during the early stages of egg production. International Journal of Poultry Science, 2007, 6: 637-641.

23. Epimakhova E.E., Shcherbakova N.G. Ptitsa $i$ ptitseprodukty, 2013, 5: 44-46 (in Russ.). 
24. Ale k s e v F.F., Kurilkin S.F., Filo ne nko V.I., S hol' V.G. Sposob preryvaniya instinkta nasizhivaniya $u$ indeek. A.S. 1351552 (SU) MKI3 A 01 K 67/02. VNITIP (SU). № 4032856/30-15. Zayavl. 16.12.85. Opubl. 15.11.87. Byul. № 42 [Method of interrupting brooding in turkey. AC 1351552 (SU) MKI3 A 01 K 67/02. VNITIP (SU). № 4032856/30-15. Appl. December 16, 1985. Publ. November 11, 1987. Bul. № 42] (in Russ.).

25. Ad a m s G.P., Rat to M.H., S i lva M.E., C a r rasco R.A. Ovulation-inducing factor (OIF/NGF) in seminal plasma: a review and update. Proc. 20th Annual Conf. of the European Society for Domestic Animal Reproduction (ESDAR) and the 13th Conf. of the Spanish Association for Animal Reproduction (AERA). Lisbon, 2016: 4-17 (doi: 10.1111/rda.12795).

26. Ples hanov N.V., St a nish evskaya O.I., Fedorova E.S., Gal'pern I.L. Metodicheskoe posobie po iskusstvennomu osemeneniyu kur [Artificial insemination in hens - toolkit]. St. Petersburg-Pushkin, 2015 (in Russ.).

27. Ples hanov N.V. Izvestiya Sankt-Peterburgskogo gosudarstvennogo agrarnogo universiteta, 2014, 37: $72-75$ (in Russ.). 